\title{
An Experimental Study Using the Statistical Tool D-optimal Design for the Process Optimization to Enhance the Yield of $\beta$-galactosidase from Lactobacillus plantarum
}

\author{
Nivetha Anbalagan, Mohanas rinivasan Vaithilingam* \\ School of BioSciences and Technology, Vellore Institute of Technology (VIT), Vellore, Tamil Nadu, INDIA.
}

\begin{abstract}
Context: The Novelty of the research is to formulate the probiotic product with lowcost submerged fermentation for the mitigation of lactose intolerance. The utilization of substrate enhances the production of $\beta$-galactosidase from the potent strain Lactobacillus plantarum by optimizing the media using the response surface methodology tool. This research is expected to result in innovative scientific outcomes leading to the development of lactose-free products cheaply. Aim: The current research is focused on the optimization of cultural conditions using a D-optimal experimental design to enhance the yield of $\beta$-galactosidase. Materials and Methods: Interaction of two physical and chemical factors such as lactose $0.5-2 \%$, beef extract $0.5-2 \%, \mathrm{pH} 6-8$, and temperature $30-40^{\circ} \mathrm{C}$, were studied in $3 \mathrm{D}$ interaction. $\beta$-galactosidase production was estimated using the hydrolysis of o-Nitrophenyl $\beta$-D-galactopyranoside as the substrate. Further, the enzyme was purified by $70 \%$ precipitation, fractionated with $50-k D a$ ultra-filtration, and separated in gel permeation chromatography with the matrix Sephadex-G100. The extracted $\beta$-galactosidase from Lactobacillus plantarum has been immobilized in alginate and hardened with calcium chloride for lactose hydrolysis using Glucose oxidasePeroxidase assay. Results: The molecular sequencing of VITDM15 was confirmed as Lactobacillus plantarum in 16srRNA sequencing. Using the optimized conditions there was a six-fold increase in the yield of $\beta$-galactosidase. The purified $\beta$-galactosidase from Lactobacillus plantarum KX838907 yielded $31.75 \%$ with 67.73 fold and specific activity of $1705 \mathrm{IU} / \mathrm{mg}$. The molecular weight of the enzyme was found to be $112 \mathrm{kDa}$ at denaturing conditions in sodium dodecyl sulfate-polyacrylamide gel electrophoresis. In GOD-POD assay the glucose dosage increased up to a maximum level of $4.891 \mathrm{mg} / \mathrm{l}$ in the $4^{\text {th }}$ cycle. Conclusion: Based on the results obtained we claim that this might be the first report on the enhanced yield of $\beta$-galactosidase and lactose hydrolysis. Thus novel strain Lactobacillus plantarum KX838907 can be used in the commercial production of $\beta$-galactosidase as it is considered safe to use as a probiotic microorganism.
\end{abstract}

Key words: $\beta$-galactosidase, D-Optimal, SDS-PAGE, Sodium alginate, Lactose hydrolysis.

\section{INTRODUCTION}

This research discusses one of the most appropriate problems in abdominal clinical practice: LACTOSE INTOLERANCE- when there is a lack of a $\beta$-galactosidase enzyme in the digestive tract. It is a clinical disorder and the widespread condition differs from one individual to another with one or more symptoms such as vomiting sensation, abdominal pain, diarrhea, nausea, gas/ flatulence, emergency to go for the toilet, abnormal stomach, etc., People sensitive to lactose are not able to take dairy products, which deliver a major source of calcium. If dairy products are eliminated from the human body, they can be the lack calcium and finally leads to bone diseases called osteoporosis. To absorb calcium, our body needs Vitamin D which is again rich in
Submission Date: 20-11-2020; Revision Date: 25-05-2021; Accepted Date: 18-10-2021

DOI: 10.5530/ijper.55.4.210 Correspondence:

Dr. V. Mohanasrinivasan, Associate Professor, School of Bio Sciences and Technology, Vellore Institute of Technology Vellore-632014, Tamil Nadu, INDIA.

Phone: +91 9486802902, Email -v.mohan@vit.ac.in

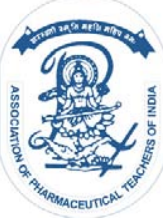

www.ijper.org 
milk, yogurt, curd, butter, etc., In this case, lactose intolerance people can go with lactose-free products. The intestinal lining of the digestive tract produces a catalyst called lactase that hydrolyzes the dietary lactose from dairy items to beat lactose narrow-mindedness inadequacy. ${ }^{1,2}$ About $60 \%$ of people in the world having difficulty digesting lactose and that leads to a syndrome called lactose intolerance and reduces their quality of life. ${ }^{3}$ Lactose intolerance can be treated by utilizing extra probiotic microbes like Lactobacilli or $\beta$-galactosidase catalysts that can hydrolyze the lactose sugar present in dairy items. Yet, the utilization of lactic acid bacteria as a probiotic is confined to treat the lactose narrow mindedness because it fails to frame spores and persevere through the acidic condition of the stomach. ${ }^{4}$

$\beta$-galactosidase is also called lactase enzyme plays a major role in lactose intolerance. Enzymes are proteins that help us to cause chemical changes in the body. The small intestine breaks down food and absorbs nutrients from the food. As the same principle, the small intestine produces an enzyme called $\beta$-galactosidase break down to lactose and is absorbed into the bloodstream for the conversion of glucose and galactose. If the small intestine doesn't make enough or absence of the $\beta$-galactosidase enzyme the dairy products will not digest and leads to lactose intolerance. $\beta$-galactosidase is most commonly used in dairy products for proper digestion to improve sweetness, solubility, and flavor in food industries. ${ }^{5}$ For the utilization of dairy items with no extreme side effects for lactose-intolerance individuals, $\beta$-galactosidase enzymatic hydrolysis is one of the most standard procedures for lactose-free product development. ${ }^{6-9}$

The enzyme is also found in animal organs like in the digestive tract, cerebrum, placenta and testis of mutts, hares, snails, calves, sheep, goats, rodents. ${ }^{10}$ Moreover, $\beta$-galactosidase is also found in human salivation, in hatchlings of primates and domesticated animals, in tissues of rodents and mice, and the plasma serum and pee of mutts. ${ }^{11} \beta$-galactosidase is produced by some microorganisms. They are produced from yeasts such as Kluyveromyces lactis, from fungi such as Neurosporacroussa, Aspergillus foetidus, ${ }^{12}$ from bacterial cultures like Bacillus megaterium, Escherichia coli, Thermus aquaticus, Streptococcus thermophilus, Lactobacillus bulgaricus. ${ }^{13}$ Furthermore, lactose intolerance is not milk hypersensitivity; People regularly confuse milk sensitivity and lactose intolerance due to the similarity of manifestation. Be that as it may, lactose intolerance contrasts extraordinarily with milk sensitivity. ${ }^{14,15}$ Lactose intolerance includes the stomachrelated system through milk sensitivity includes the immune system.
Hence the objective of the study is focused on the optimization of $\beta$-galactosidase production from Lactobacillus plantarum VITDM15 using the statistical tool D-optimal experimental design Response Surface Methodology. Further, the enzyme purified for the maximum yield and its application in lactose hydrolysis. The novelty of the research is to enhance the yield of $\beta$-galactosidase for lactose-free product development using the probiotic bacteria which is considered to be Generally Recognized as Safe (GRAS).

\section{MATERIALS AND METHODS}

\section{Chemicals}

Mann Ragosa Sharpe broth or agar (MRS), lactose, sodium alginate, yeast extract, beef extract, OrthoNitrophenyl- $\beta$-galactoside (ONPG) (Himedia, Mumbai, India) chloroform, toluene, acetone, high range protein marker (SRL chemicals, Chennai, Tamil Nadu, India) were purchased.

\section{Probiotic bacteria strain VITDM15 and culture condition}

Lactic Acid Bacteria (LAB) isolated from donkey milk, curd and yogurt were screened for $\beta$-galactosidase using X-gal (5-bromo-4-chloro-3-indolyl- $\beta$-D-galactopyranoside) in our previous paper. ${ }^{16}$ Out of this, the potent strain VITDM15 was taken for further study. The stock culture was maintained at $-20^{\circ} \mathrm{C}$ in Mann Ragosa Sharpee broth (MRS) with 20\% (v/v) glycerol. It was retrieved and multiplied twice in MRS broth before the conduct of experiments. The strain VITDM15 will be identified based on the biochemical and $16 \mathrm{~S}$ rRNA sequencing.

\section{$\beta$-galactosidase production of the cell-free extract by ONPG method}

The capacity of $\beta$-galactosidase production was estimated using the hydrolysis of Ortho-Nitrophenyl $\beta$-Dgalactoside (ONPG) as the substrate. The positive strain VITDM15 from the X-Gal assay was grown in MRS broth and the overnight culture was centrifuged at $12,000 \mathrm{rpm}$ for $20 \mathrm{~min}$ at $4^{\circ} \mathrm{C}$. Obtained culture pellet $(100 \mu \mathrm{l})$ mixed with $900 \mu \mathrm{l}$ of $\mathrm{Z}$-Buffer $\left(\mathrm{Na}_{2} \mathrm{HPO}_{4}\right.$, $\mathrm{NaH}_{2} \mathrm{PO}_{4}, \mathrm{KCl}, \mathrm{MgSO}_{4}, \beta$-Mercaptoethanol) with $\mathrm{pH}$

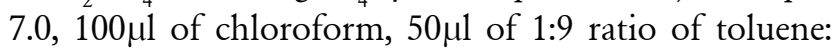
acetone and disrupted using probe sonicator $(\mathrm{pH}$ meterSystronics). To the disrupted cells $200 \mu$ l of ONPG $(4 \mathrm{mg} / \mathrm{ml}$ of Z-Buffer) was added and reacted for $15 \mathrm{~min}$ at $37^{\circ} \mathrm{C}$. The yellow color was observed which determines the presence of $\beta$-galactosidase activity. The $\beta$-galactosidase catalysis reaction was stopped by adding $200 \mu \mathrm{l}$ of $1 \mathrm{M} \mathrm{Na}_{2} \mathrm{CO}_{3}$ and the optical density value noted 
at 420 and $550 \mathrm{~nm}$ for each isolate. The $\beta$-galactosidase value was calculated by the standard formula. The one isolate VITDM15 exhibited maximum enzyme activity was characterized for $16 \mathrm{~S}$ rRNA sequencing, optimized by RSM followed with purification and immobilized for lactose hydrolysis. ${ }^{17,18}$

$$
\beta=\text { galactosidase }=100 \times \frac{\mathrm{OD} 420 \mathrm{~nm}}{\mathrm{~T} \times \mathrm{V} \times \mathrm{OD} 600 \mathrm{~nm}}
$$

\section{Molecular characterization of Lactobacillus}

The species-level identification for the potent strain VITDM15 was obtained by $16 \mathrm{~S}$ rRNA sequencing and followed for the construction of a phylogenetic tree using MEGA 5.05 software. Genomic DNA was extracted from bacterial isolate (Yazzh genomics) according to the manufactures instruction. The universal primers 27F (5'-AGAGTTTGATCCTGGCTCAG-3') and 1492R (5'-GGTTACCTTGTTACGACTT-3') are used for the species-level identification. The acquired sequences were processed in BLASTn for sequence homology and submitted in the NCBI database to get the Genbank accession number. The partial sequence obtained from $16 \mathrm{~S}$ rRNA was constructed for the phylogenetic tree using MEGA software by the neighbor join method. ${ }^{19,20}$

\section{Scanning Electron Microscope (SEM)}

The aliquots of fresh $L$. plantarum culture was incubated for $48 \pm 2 \mathrm{hr}$ at $37^{\circ} \mathrm{C}$ and was harvested, fixed, dehydrated, and essentially embedded respectively according to McDougall et al. ${ }^{21}$ The overnight culture was smeared on the coverslip and fixed for $1 \mathrm{~h}$ in a solution containing 2.5\% glutaraldehyde. A Further coverslip was dehydrated using 70\% ethanol and final immersion in $100 \%$. Subsequently, the coverslip was subjected to $2.5 \%$ glutaraldehyde and allowed to dry overnight. Microscopic analysis was carried out with a scanning electron microscope (Leo Electron Microscopy Ltd. Cambridge, UK) operated at $10 \mathrm{keV}$.

\section{Primary optimization stage}

The production media was inoculated with $L$. plantarum VITDM15. After the incubation, cells were harvested by centrifugation and disrupted using ultra-sonication to analyze the activity of $\beta$-galactosidase. To optimize the physical and chemical parameters using the one factorat-a-time method (OFAT), the effect of carbon and the nitrogen source was replaced in the MRS medium and tested for the enhanced yield of $\beta$-galactosidase. Various carbon and nitrogen sources were selected for one factor-at-a-time method (OFAT) study using $L$. plantarum.
The carbon source (maltose, lactose, fructose, and starch) were added at $1 \%(\mathrm{w} / \mathrm{v})$ and the influence of nitrogen sources (beef extract, yeast extract, peptone, and ammonium nitrate) in a modified MRS medium was replaced by protease peptone with $1 \% \mathrm{w} / \mathrm{v}$ and tested for the enhance yield of $\beta$-galactosidase. The same way effect of temperature was determined by incubating the potential strain at a different temperature such as $30^{\circ} \mathrm{C}, 40^{\circ} \mathrm{C}$, and $50^{\circ} \mathrm{C}$ and $\mathrm{pH} 3,5,7,9$, and 11 respectively. For each parameter, a blank sample was maintained. The culture was allowed to grow for $48 \mathrm{~h}$ at $37^{\circ} \mathrm{C}$ and the activity of $\beta$-galactosidase was determined by ONPG analysis in triplicates and reports as mean value.

\section{Experimental design by RSM (D-optimal design)}

Based on the results obtained in the classical method (OFAT), lactose as a carbon source and beef extract as a nitrogen source are selected as chemical variables. Along with these conditions temperature and $\mathrm{pH}$ were selected as additional physical variables. The production of $\beta$-galactosidase from $L$. plantarum VITDM15 was analyzed by statistical tool D-optimal experimental design using RSM. The experimental design summary was predicted with 26 experimental trials with D-optimal initial design by the quadratic model (Design-Expert 7.0.0, StatEase, Inc., Minneapolis, USA). An experimental design was formulated with different concentrations of lactose and beef extract at different temperatures and $\mathrm{pH}$ with $1 \%$ inoculums in a $500 \mathrm{ml}$ erlenmeyer flask. To determine the dependent variable response in $\beta$-galactosidase production and to establish the specific interactions of different factors and also to evaluate the conditions to optimize the responses $3 \mathrm{D}$ contour plots were plotted. To evaluate the effect of four variables 26 sets of experiments were carried out with lactose (0.2-1\%), beef extract (0.5-1\%), $\mathrm{pH}(6-8)$, and temperature $\left(25-45^{\circ} \mathrm{C}\right)$ concentration with 2 coded levels $(-1,+1$ level) used for their combined influence the production of $\beta$-galactosidase (gL-1).

\section{$\beta$-galactosidase production and purification}

The production and purification of $\beta$-galactosidase from L. plantarum VITDM15 were grown in the production media under optimized conditions. Cells were removed by centrifugation at $8000 \mathrm{rpm}$ at $4^{\circ} \mathrm{C}$ for $20 \mathrm{~min}$. The pellet was disrupted using a probe sonicator and ammonium sulfate was added slowly to achieve $70 \%$ saturation. The precipitated protein was collected and solubilized in Z-buffer (0.1M, pH 7.2). ${ }^{22}$ The protein was then ultra-filtered with $50 \mathrm{Kda}$ cut off the membrane (Amicon, Millipore) and the collected retentate was 
collected loaded onto a sephadex G-100 column. To find out the elution of the protein the absorbance of the protein was recorded at $280 \mathrm{~nm} .{ }^{23}$ The eluted protein was estimated by lowry's method using Bovine Serum Albumin (BSA) as a standard. ${ }^{24}$ Purified $\beta$-galactosidase was subjected to molecular weight determination using 12\% SDS-PAGE (Bio Rad) with a standard high range protein marker $(20-206 \mathrm{kDa}$, SRL). All the purification steps were analyzed for both $\beta$-galactosidase activities by ONPG assay and protein estimation by lowry's method to construct the purification table. The specific activity of an enzyme, purification folds, and yield percentage were calculated.

\section{Application study on immobilized $\beta$-galactosidase used to make lactose-reduced milk}

In a $2 \%$ sodium alginate solution the purified enzyme was mixed properly. The alginate enzyme slurry was taken in the syringe and dropped onto the 1.5\% calcium chloride solution and beads were collected $(2.5 \mathrm{~g})$. The immobilized enzyme-containing was allowed to harden for an hour. Immobilized matrix packed in $20 \mathrm{ml}$ syringe with a height of $1.5 \mathrm{~cm}$. The syringe was connected with a short-length tube to the tip of the syringe barrel and nylon gauze was placed inside the barrel to prevent the beads from blocking the syringe outlet. The fresh milk sample was treated with an immobilized enzyme in a syringe and again returns the treated milk in the syringe to reach the desired concentration of glucose. A total of 4 cycles were carried out and all four cycles were analyzed for glucose content by GOD-POD assay, therefore glucose $(0.4 \mathrm{mg} / \mathrm{mL})$ was used as standard and fresh milk as reference. The glucose content was measured in units before and after treating milk with enzyme and calculated with a standard formula. The percentage value was also calculated for the improvement of glucose $(\mathrm{mg} / \mathrm{l})$ dosage in each cycle. The diagrammatic flow chart for the study is shown in Figure 1.

$$
\mathrm{C}(\mathrm{D}-\text { Glucose })=\frac{\text { Sample } \Delta \mathrm{A}}{\text { Glucose standard } \Delta \mathrm{A}} \times 1000
$$

\section{RESULTS AND DISCUSSION}

\section{Isolation of $\beta$-galactosidase producing Lactobacilli}

The current study was carried out to investigate the efficiency of $\beta$-galactosidase production from different bacterial isolates. The maximum $\beta$-galactosidase production was noted in one strain isolated from donkey milk with 3222IU and named VITDM15. The estimation of $\beta$-galactosidase activity by ONPG assay

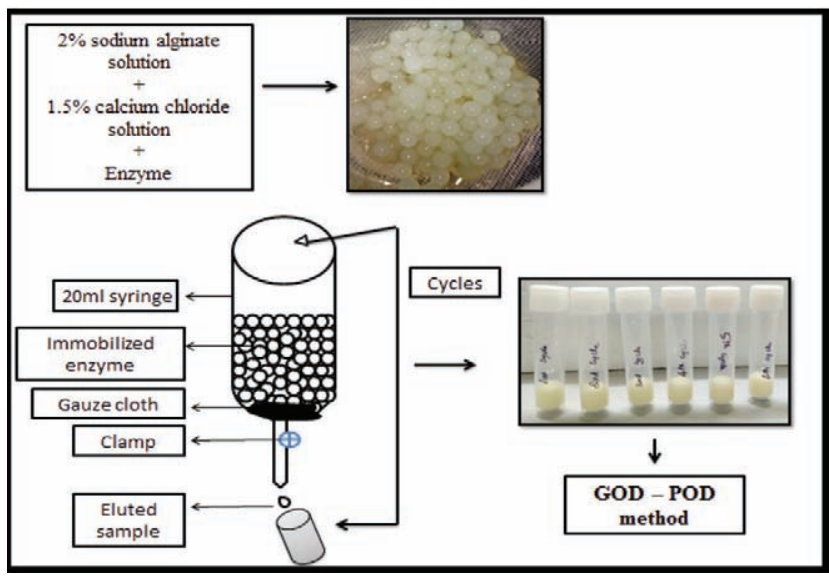

Figure 1: Diagrammatic flow chart for application study on immobilized $\beta$-galactosidase.

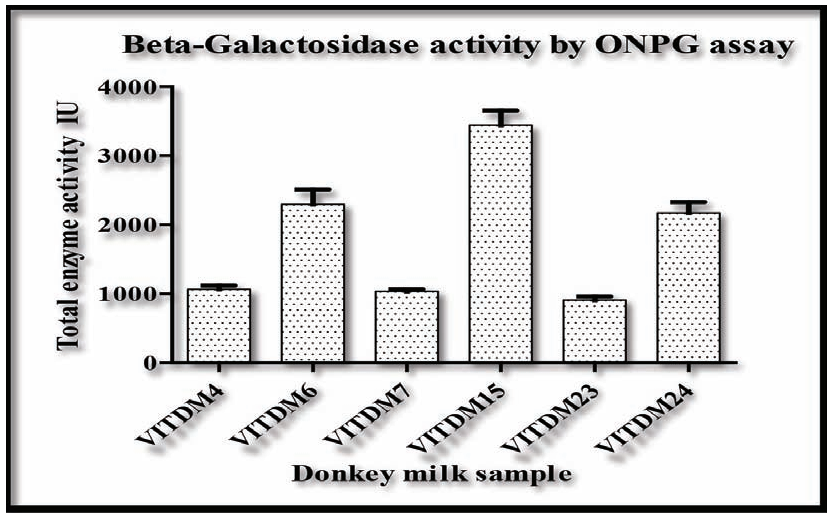

Figure 2: Estimation of $\beta$-Galactosidase activity by ONPG assay for crude (Donkey milk).

for crude (donkey milk) is represented in Figure 2. The one potent isolate VITDM15 was identified for the biochemical characterization with rod shape gram-positive bacteria and negative for catalase test. The biochemical and probiotic property specifies that the strain belongs to lactic acid bacteria. From the results obtained, it is evident that the $\beta$-galactosidase produced by the strain VITDM15 was comparatively more active than the results reported DIY11 335U/min/cell yeast earlier by Al-jazairi et al. ${ }^{18}$ Thus the VITDM15 potent strain Lactobacilli was subjected to 16s rRNA sequencing and phylogenetic tree construction. Similarly, it is also carried out for extraction, optimization, purification, and immobilization of the enzyme for lactose hydrolysis.

\section{Molecular sequencing of potent isolate Lactobacilli}

The partial 16s rRNA sequence obtained was exported to the database and checked for homology alignment. The alignment results of VITDM15 exhibited 99\% similarity with $L$. plantarum. The sequence of the strain 


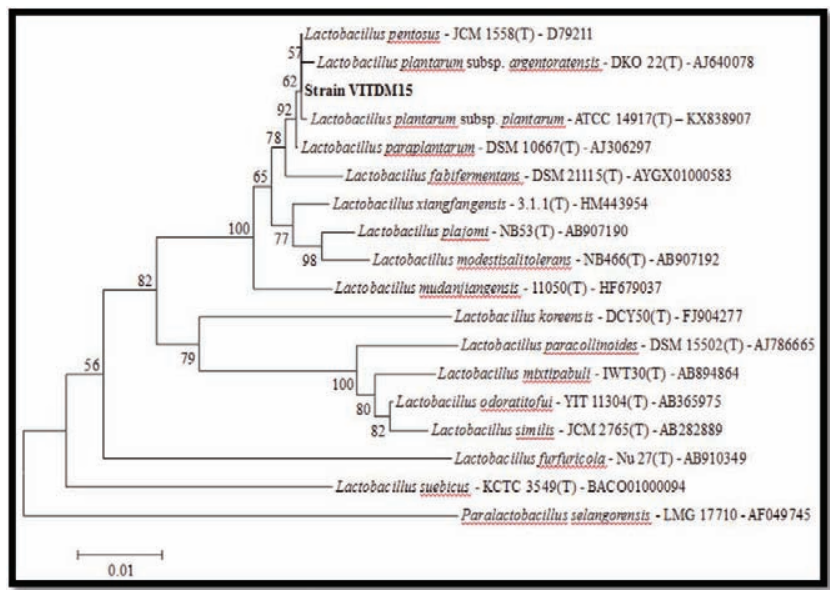

Figure 3: The neighbor-joining method cladogram showing a phylogenetic relationship between Lactobacillus plantarum VITDM15 and other related Lactobacillus plantarum based on the 16s rRNA gene sequence analysis.

has been submitted to NCBI and the gene bank accession number was obtained as KX838907 for L. plantarum. Thus the study reveals the identification of L. plantarumVITDM15 from donkey milk with the efficient production of $\beta$-galactosidase. Murua et al. also reported the isolation of $L$. plantarum from donkey milk samples. ${ }^{25}$ The phylogenetic tree was constructed between L. plantarum and other related Lactobacillus species based on 16s rRNA gene sequencing using MEGA 5 in Figure 3.

\section{Scanning Electron Microscope (SEM)}

The SEM images revealed the bacterial cell size, shape, length, diameter, and physical morphology of the bacteria. The cells were found to be attached to the surface of the coverslip which was immersed in the MRS broth for $48 \mathrm{~h}$. The SEM analysis showed that the cells were rod in shape at $10.30 \mathrm{KX}$ magnification observed in Figure 4. The length of the cell was observed to be $2 \mu \mathrm{m}$ and $13.5 \mathrm{~mm}$ in diameter.

\section{Optimization study on $\beta$-galactosidase production from L. plantarum}

Carbon and nitrogen source are essential nutrients for the effective production of $\beta$-galactosidase. The most effective carbon source to obtain maximum $\beta$-galactosidase production was found to be lactose $(1170.00 \mathrm{U} / \mathrm{mL})$ followed by maltose $(965.00 \mathrm{U} / \mathrm{mL})$, fructose $(744.66 \mathrm{U} / \mathrm{mL})$, and starch $(345.00 \mathrm{U} / \mathrm{mL})$. Therefore lactose was identified to be the best carbon source to enhance the maximum enzyme activity when compared to other carbon sources. Among the different nitrogen sources, the beef extract was observed with the maximum production of $\beta$-galactosidase with $1356.67 \mathrm{U} / \mathrm{mL}$. Yeast extract revealed $864.66 \mathrm{U} / \mathrm{mL}$

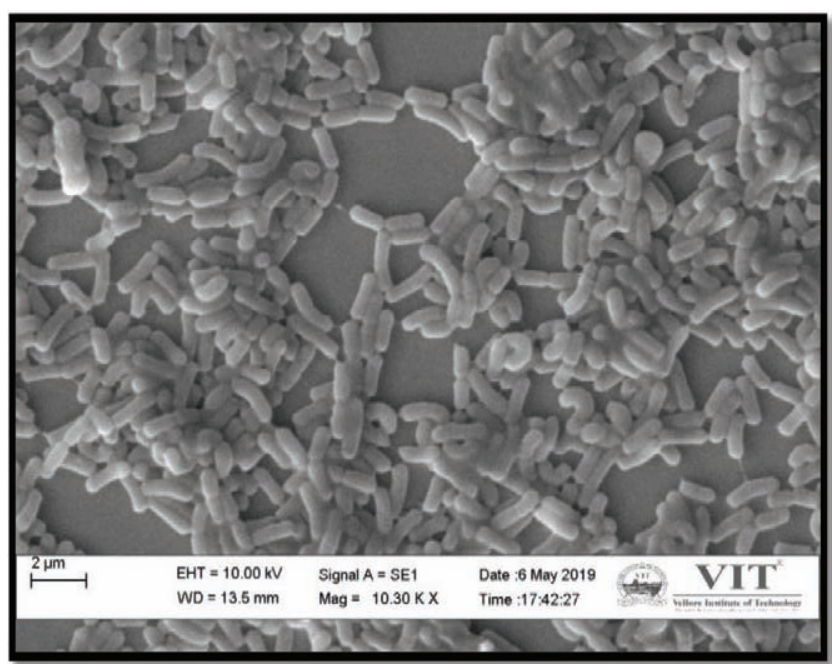

Figure 4: SEM analysis of Lactobacillus plantarum at $10.30 \mathrm{KX}$ magnifications.

followed by that peptone and ammonium nitrate were found to be $544.66 \mathrm{U} / \mathrm{mL}$ respectively. A similar result was reported by Siham et al. in the case of B.circulans. ${ }^{26}$ The consequence of $\mathrm{pH}$ and temperature on $L$ plantarum KX838907 was analyzed for $\beta$-galactosidase activity. The enzyme was more active in temperature ranging from $30^{\circ} \mathrm{C}$ to $40^{\circ} \mathrm{C}$, with an optimum value around $40^{\circ} \mathrm{C}(1419.86 \mathrm{U} / \mathrm{mL})$ and slowly decreased from $40^{\circ} \mathrm{C}$ to $50^{\circ} \mathrm{C}$. Therefore the isolate was able to survive and produce $\beta$-galactosidase with least to maximum temperature. This optimum temperature for $\beta$-galactosidase production was similar to the results reported by Desire et al. in Bacillus sp. ${ }^{27}$ The stability of the $\mathrm{pH}$ for enzyme production was investigated from acidic to basic condition. The enzyme fairly can be extracted and stable at $\mathrm{pH} 7$ with $1149.11 \mathrm{U} / \mathrm{mL}$ and it rapidly decreased from $\mathrm{pH} 8$ to $\mathrm{pH} 11$. This study showed the ability to produce $\beta$-galactosidase from L. plantarum in different carbon and nitrogen sources followed by temperature and $\mathrm{pH}$ in Figure 5 (A).

\section{Statistical analysis RSM}

The results obtained in the OFAT approach revealed the optimum levels of significant factors. The effect of their interactions on $\beta$-galactosidase production was further confirmed with enhanced productivity using RSM the statistical tool called D-optimal experimental design with varying parameters. The design expert of the D-optimal model was enhanced to optimize the $\beta$-galactosidase production by varying the parameters (A) temperature, (B) $\mathrm{pH},(\mathrm{C})$ lactose (D) beef extract. Parameters were selected based on the result of the primary optimization method. The experimental design determines the parameter factors ranges together with 
(A)
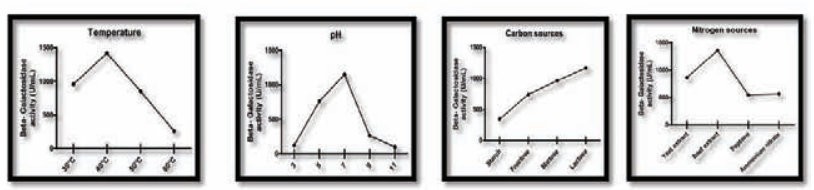

(B)

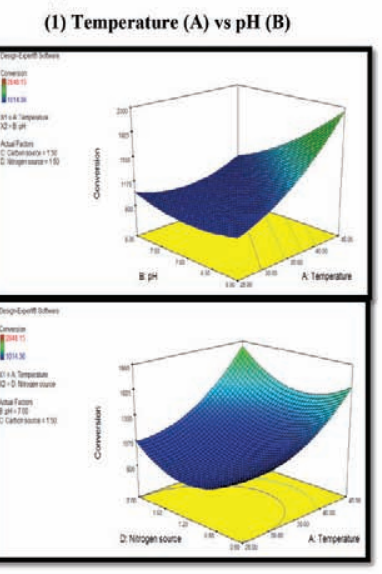

(2) Carbon (C) vs Temperature (A)

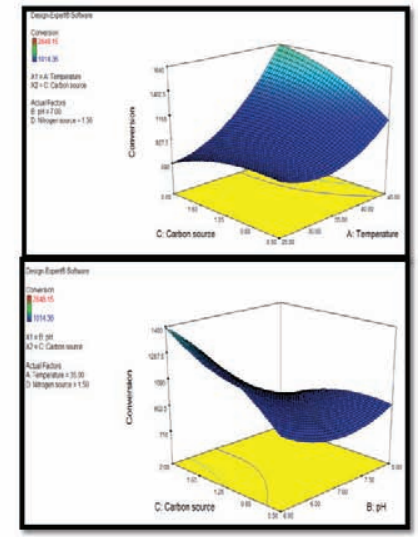

(5) Nitrogen (D) vs pH (B)

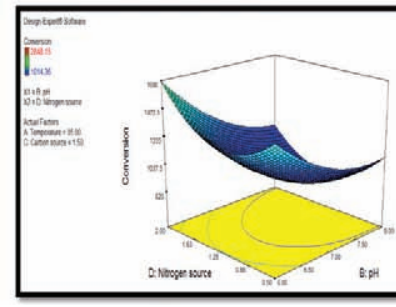

(6) Nitrogen (D) vs Carbon (C)

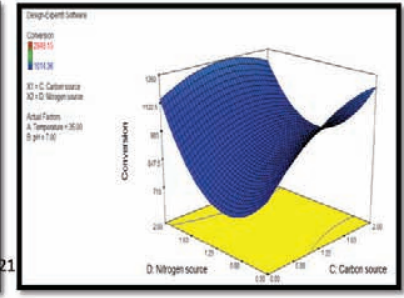

Figure 5: (A) Effect of $\beta$-galactosidase on temperature, $\mathrm{pH}$, carbon and nitrogen sources

(B) Response surface plot in relation to different parameters for $\beta$-galactosidase production.

the coded and actual values from lower to upper-level variables for $\beta$-galactosidase production. The results of the 26 runs from D-optimal experiments study the effects of 4 independent variables on $\beta$-galactosidase production. The maximum experimental value for $\beta$-galactosidase production was $2848.15 \mathrm{IU} / \mathrm{mL}$ based on RSM. Parameters were optimized by D-optimal design with three central points and the response of $\beta$-galactosidase yield was studied. Design expert 7.0.0 was used to predict the values, regression analysis, and experimental design with obtained data. The enzyme activity expressed in the design expert was computed by analysis of variance (ANOVA) to check the quality of fit of the polynomial expression to predict the responses.

$3 \mathrm{D}$ interaction between the different parameters of the media was optimized to enhance the production of $\beta$-galactosidase by L. plantarum VITDM15 by RSM design expert tool, where (1) represents temperature (A) vs $\mathrm{pH}(\mathrm{B}),(2)$ carbon (C) vs temperature (A), (3) nitrogen
(D) vs temperature (A), (4) carbon (C) vs $\mathrm{pH}(\mathrm{B}),(5)$ nitrogen (D) vs $\mathrm{pH}(\mathrm{B}),(6)$ nitrogen $(\mathrm{D})$ vs carbon $(\mathrm{C})$ is shown in Figure 5 (B). The statistical significance and the analysis of variance (ANOVA) for the quadratic model - response for $\beta$-galactosidase production tabulated in Table 1.

The regression analysis data were fitted to a quadratic model and the second-order regression equation obtained was a full actual model on $\beta$-galactosidase production as shown in equation 1 .

$\beta$-galactosidase production $=+917.20+277.19^{*} \mathrm{~A}$ $-188.27 * \mathrm{~B}+98.59 * \mathrm{C}+67.64 * \mathrm{D}$

$-305.23 * A^{*} \mathrm{~B}+178.53^{*} \mathrm{~A}^{* \mathrm{C}} \mathrm{C}+48.15^{*} \mathrm{~A}$ * $\mathrm{D}-173.68^{*} \mathrm{~B} * \mathrm{C}$

$-49.03 * B * D-71.19 * C^{*} D+205.00 * A^{2}+133.08 * B^{2}$

$-83.62 * \mathrm{C}^{2}+268.64 * \mathrm{D}^{2}$

Where $\mathrm{A}$ is temperature, $\mathrm{B}$ is $\mathrm{pH}, \mathrm{C}$ is a carbon $(\mathrm{g} / \mathrm{L})$ and $\mathrm{D}$ is nitrogen source $(\mathrm{g} / \mathrm{L})$

From ANOVA, the model F-value determines 11.54 for $\beta$-galactosidase production and it reveals that the model is significant. This is likewise obvious from the model $\mathrm{F}$ esteem and the probability value at $P>\mathrm{F}$ was about 0.0500 . There is just a $0.02 \%$ possibility that a "Model F-value" this huge could happen because of noise. The adequacy of the model can be analyzed by a coefficient $\left(R^{2}\right)$ and the connection coefficient (R). ${ }^{28,29}$ The $R^{2}$ estimation of 0.9417 suggests $94.17 \%$ fluctuation in $\beta$-galactosidase extraction. In this case, $A, B, A B, A C$, BC, D2 are huge model terms. The "Lack of Fit F-value" of 3500.29 includes the lack of fit is significant.

Purification of $\beta$-galactosidase from the optimized media for maximum yield

Purification of $\beta$-galactosidase was done in three steps, includes ammonium sulfate precipitation, ultracentrifugation, and gel permeation chromatography with sepahdex G100. In ammonium sulfate precipitation assay, at $70 \%$ of saturation, the precipitated protein showed the highest $\beta$-galactosidase activity. Further, from ultracentrifugation, the retentate was collected and eluted in gel permeation chromatography at $0.5 \mathrm{~mL} / \mathrm{min}$ of flow rate. A total of 22 fractions were collected and maximum activity was determined between $5^{\text {th }}$ and $6^{\text {th }}$ fractions at $280 \mathrm{~nm}$. Enzyme activity, protein estimation, specific activity, and yield percentage were calculated in purification Table 2.

Summary of purified $\beta$-galactosidase from $L$. plantarum KX838907 was yielded $31.75 \%$ with 67.73 fold and specific activity of $1705 \mathrm{IU} / \mathrm{mg}$. The purity of the protein yielded with $0.6 \mathrm{mg}$ with $1235 \mathrm{IU}$ enzyme acitivity. To the best of our knowledge, this is the first report on $\beta$-galactosidase with maximum yield and analyzed for lactose hydrolysis. There are reports which showed 
Table 1: ANOVA for the quadratic model - response for $\beta$-galactosidase production and R-squared, Adj R-squared, Pred R-squared, and Adeq precision value of the model.

\begin{tabular}{|c|c|c|c|c|c|c|}
\hline Source & Sum of squares & $\mathrm{d}_{f}$ & Mean square & $F$ value & $p$-value Prob $>F$ & \\
\hline Block & 59013.29 & 1 & 59013.29 & & & \\
\hline Model & $6.42 E+06$ & 14 & $4.59 \mathrm{E}+05$ & 11.54 & 0.0002 & Significant \\
\hline A-Temperature & $1.18 \mathrm{E}+06$ & 1 & $1.18 E+06$ & 29.68 & 3.00E-04 & \\
\hline B-pH & $5.68 \mathrm{E}+05$ & 1 & 5.681E_005 & 14.29 & 3.60E-03 & \\
\hline C-Carbon source & $1.68 \mathrm{E}+05$ & 1 & $1.68 \mathrm{E}+05$ & 4.23 & 0.0667 & \\
\hline D-Nitrogen source & $7.49 \mathrm{E}+04$ & 1 & $7.49 \mathrm{E}+04$ & 1.88 & 2.00E-01 & \\
\hline$A B$ & $1.23 E+09$ & 1 & $1.23 E+06$ & 30.97 & 2.00E-04 & \\
\hline$A C$ & $3.79 \mathrm{E}+05$ & 1 & $3.79 \mathrm{E}+05$ & 9.54 & 1.15E-02 & \\
\hline$A D$ & $2.84 \mathrm{E}+04$ & 1 & $2.84 \mathrm{E}+04$ & 0.71 & 4.18E-01 & \\
\hline $\mathrm{BC}$ & $3.72 E+05$ & 1 & $3.72 E+05$ & 9.36 & $1.21 \mathrm{E}-02$ & \\
\hline $\mathrm{BD}$ & $2.79 \mathrm{E}+04$ & 1 & $2.79 \mathrm{E}+04$ & 0.7 & $4.22 \mathrm{E}-01$ & \\
\hline$C D$ & $6.13 E+04$ & 1 & $6.13 E+04$ & 1.54 & 2.43E-01 & \\
\hline $\mathrm{A} 2$ & $1.42 \mathrm{E}+05$ & 1 & $1.42 \mathrm{E}+05$ & 3.58 & 8.78E-02 & \\
\hline B2 & $5.39 \mathrm{E}+04$ & 1 & $5.39 E+04$ & 1.36 & 2.71E-01 & \\
\hline $\mathrm{C} 2$ & $2.24 \mathrm{E}+04$ & 1 & $2.24 \mathrm{E}+04$ & 0.56 & 4.70E-01 & \\
\hline $\mathrm{D} 2$ & $2.80 \mathrm{E}+05$ & 1 & $2.80 \mathrm{E}+05$ & 7.05 & 2.41E-02 & \\
\hline Residual & $3.98 \mathrm{E}+05$ & 10 & $3.98 \mathrm{E}+04$ & & & \\
\hline Lack of Fit & $3.97 \mathrm{E}+05$ & 5 & $7.95 \mathrm{E}+04$ & 3500.29 & $<0.0001$ & Significant \\
\hline Pure Error & $1.14 \mathrm{E}+02$ & 5 & $2.27 \mathrm{E}+01$ & & & \\
\hline Cor Total & $6.88 \mathrm{E}+09$ & 25 & & & & \\
\hline
\end{tabular}

\begin{tabular}{|c|c|c|c|}
\hline Std. Dev. & 199.38 & R-Squared & 0.9417 \\
\hline Mean & 1268.86 & Adj R-Squared & 0.8601 \\
\hline C.V.\% & 15.71 & Pred R-Squared & 0.0181 \\
\hline PRESS & $6.699 \mathrm{E}+006$ & Adeq Precision & 12.842 \\
\hline
\end{tabular}

\begin{tabular}{|c|c|c|c|c|c|c|}
\hline \multicolumn{2}{|c|}{ Table 2: Summary of purification of $\boldsymbol{\beta}$-galactosidase from L. plantarum. Purification fraction } \\
\hline & $\begin{array}{c}\text { Total volume } \\
(\mathbf{m} \mathbf{L})\end{array}$ & $\begin{array}{c}\text { Total enzyme } \\
\text { activity(IU) }\end{array}$ & $\begin{array}{c}\text { Total protein } \\
(\mathbf{m g})\end{array}$ & $\begin{array}{c}\text { Specific } \\
\left.\text { activity (IUmg })^{1}\right)\end{array}$ & $\begin{array}{c}\text { Purification } \\
\text { fold }\end{array}$ & $\begin{array}{c}\text { Yield } \\
\text { percentage }\end{array}$ \\
\hline Crude extract & 50 & 3222 & 128 & 25.17 & 1 & 100 \\
\hline $\begin{array}{c}70 \% \text { Ammonium } \\
\text { sulphate precipitation }\end{array}$ & 10 & 1235 & 37 & 33.37 & 1.3 & 38.33 \\
\hline Ultrafiltration & 5 & 1213 & 1.9 & 638.42 & 25.36 & 37.64 \\
\hline $\begin{array}{c}\text { Gel permeation } \\
\text { chromatography }\end{array}$ & 1 & 1023 & 0.6 & 1705 & 67.73 & 31.75 \\
\hline
\end{tabular}

low specific activity with $32.68 \mathrm{U} / \mathrm{mg}$ proteins for $\beta$-galactosidase by HebaEzz and Beltagey. ${ }^{30}$ Comparatively our results were found to be having increased in a specific activity with the results of Mozumder $e t$ al. for $\beta$-galactosidase purified by the earlier standard procedure with the specific activity of $42.67 \mathrm{U} / \mathrm{mg} .{ }^{22}$

\section{Molecular weight determination by SDS-PAGE}

The SDS-PAGE analysis of the purified enzyme revealed the molecular weight of the enzyme was $112 \mathrm{kDa}$ which was confirmed the presence of a unique band with $\beta$-galactosidase activity is showed in Figure 6. Elmira Gheytanchi et al. reported the molecular weight of $\beta$-galactosidase with a single band of $116 \mathrm{kDa} .{ }^{31}$ Thus in 


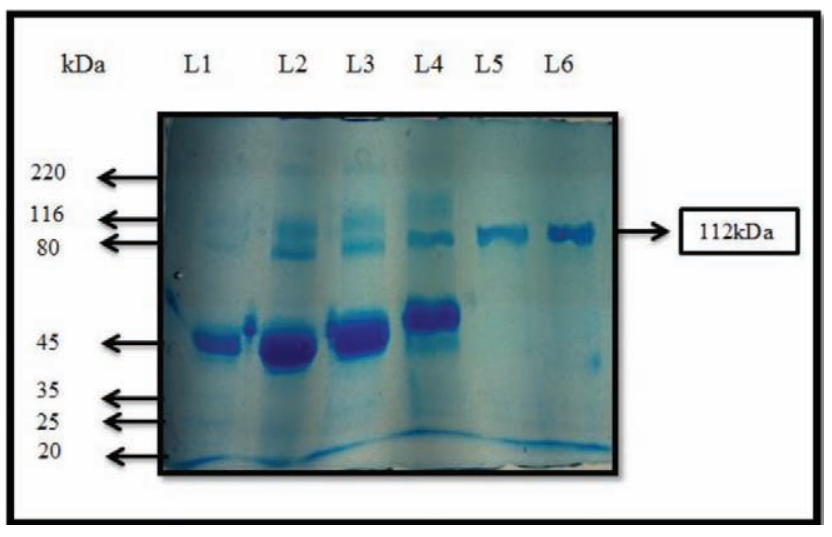

Figure 6: Purified $\beta$-Galactosidase from the potent strain Lactobacillus plantarum VITDM15. Lane 1- Protein marker (High molecular weight 20kDa to 220kDa, SRL) Lane 2- Crude enzyme; Lane 3-Ammonium sulphate precipitation; Lane 4-Retentate from ultra-filtration; Lane 5 and Lane 6- Gel permeation chromatography.

the present research work, SDS-PAGE yielded a single band, which confirms the homogeneity of the purified $\beta$-galactosidase from L. plantarum KX838907. Partially purified enzyme immobilized with sodium alginate and cross-linked with calcium chloride for the lactose hydrolysis.

\section{Storage stability of immobilized $\beta$-galactosidase}

Immobilized $\beta$-galactosidase was stored at $4{ }^{\circ} \mathrm{C}$ and the enzyme activity was analyzed. The soluble enzyme revealed $80 \%$ of enzyme activity comparatively the immobilized enzyme retained with 95\% enzyme activity after 15 days. The cross-linker can increase the stability of an enzyme that can withstand conformational changes. ${ }^{32}$

\section{Application study of immobilized $\beta$-galactosidase for lactose hydrolysis}

The milk sample was treated with an immobilized enzyme and analyzed for glucose content by the Glucose oxidase-peroxidase (GOD-POD) method. In the present study, the glucose standard was found to be $1.472 \mathrm{mg} / \mathrm{ml}$ and fresh milk $2.109 \mathrm{mg} / \mathrm{ml}$ of glucose. Hence the fresh milk was treated with immobilized $\beta$-galactosidase for the $1^{\text {st }}$ cycle and observed for the glucose dosage. The $1^{\text {st }}$ cycle of the treated milk was revealed with $2.771 \mathrm{mg} / \mathrm{ml}$ in the GOD-POD method. It is predicted that the level of glucose was increased in treated milk in comparison to fresh milk. The percentage of glucose production after the quantitative test for the $1^{\text {st }}$ cycle was recorded as $31.38 \%$. The eluted milk from the $1^{\text {st }}$ cycle was followed by the $2^{\text {nd }}$ cycle and analyzed for the glucose dosage. It is estimated the glucose dosage was about $2.965 \mathrm{mg} / \mathrm{ml}$. The concentration of glucose was moderately improved from the $1^{\text {st }}$ cycle $(31.38 \%)$ to the $2^{\text {nd }}$ cycle $(40.58 \%)$. Moreover, the obtained study revealed that the packed immobilized $\beta$-galactosidase started to release the enzyme frequently with its stability. Comparatively, the milk eluted from the $2^{\text {nd }}$ cycle subjected to the $3^{\text {rd }}$ and $4^{\text {th }}$ cycle and analyzed for the increase or decrease of glucose content like the previous procedure. The glucose content was increased steeply between the $2^{\text {nd }}$ and $3^{\text {rd }}$ cycles with $4.831 \mathrm{mg} / \mathrm{ml}(129.06 \%)$. The production of glucose can be significantly influenced by the extreme release of enzymes to bind with lactose present in the milk. This may be due to the sustainable release of the enzyme from the immobilized beads and also it is time-dependent. A maximum enzyme may be released during the third cycle hence the enzyme-substrate concentration might be more in this cycle. Because of the adequate substrate concentration with more enzymes released in this cycle, the enzyme might be acting at its maximal velocity for the conversion of lactose to glucose and galactose in this cycle. Similarly, from the $3^{\text {rd }}$ to $4^{\text {th }}$ cycles, the glucose content was further slightly increased up to $4.891 \mathrm{mg} / \mathrm{ml}$ with an increase in the percentage of 131.91. This indicates, there was a maximum glucose level rise in the $4^{\text {th }}$ cycle with an immobilized enzyme. However, the concentration of glucose seems to be high between the $2^{\text {nd }}$ and $3^{\text {rd }}$ cycles. This can be standardized in lactose hydrolysis for lactose-free product development for large-scale production in an industrial approach. This may be due to stability, fast release of an enzyme, and also eliminating the contamination of the protein. Cycles of treated milk samples with immobilized enzymes were given with an increase in the percentage value of glucose was observed in Figure 7. The concentration of glucose standard, fresh milk, and different cycles of treated milk samples was also examined in Figure 8.

\section{CONCLUSION}

This study shows its novelty by highlighting the $\beta$-galactosidase activity from potential non-pathogenic lactose fermenting $L$. plantarum which is GRAS. The maximum $\beta$-galactosidase production was achieved under optimized conditions with a maximum yield of $31.75 \%$. Enzyme immobilization was carried out for lactose-free milk as the application study by enhancing the constancy and minimizes the chance of product contamination. Also, using immobilized enzyme improve recovery and reuse of expensive catalyst. The milk sample was treated with enzyme and analyzed for the glucose content by the GOD-POD method. After the treatment, the glucose dosage increased up to a 


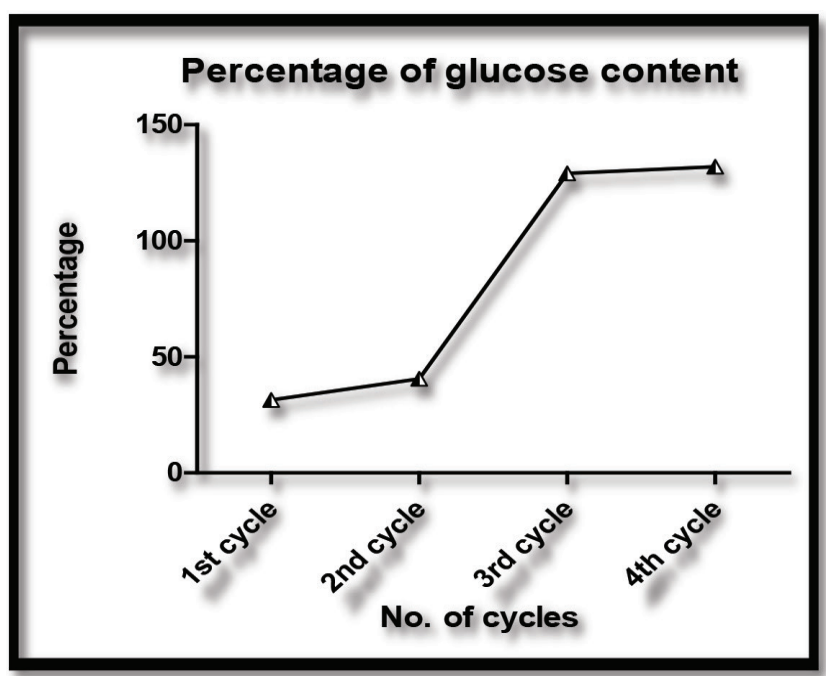

Figure 7: Percentage value of glucose content for each cycle of the treated sample.

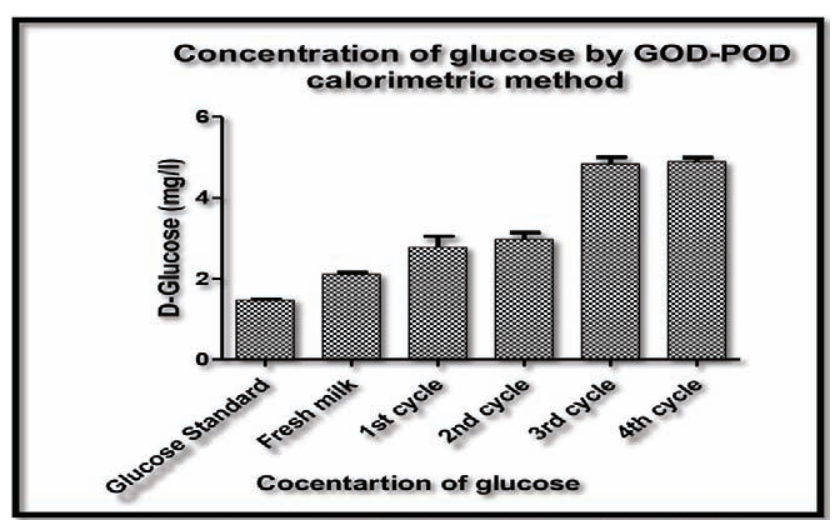

Figure 8: Concentration of glucose for each cycle by GOD - POD method.

maximum level of $4.891 \mathrm{mg} / \mathrm{l}$ in the $4^{\text {th }}$ cycle. The milk treated with enzyme was found to have less lactose and can be used by lactose-intolerant individuals in the hope to overcome health issues such as nutrient deficiency, osteoporosis disease. The problem is that there is no domestic production of lactose-free milk reported in India, but every day the consumption of lactose-free milk is getting increased. Thus novel strain L. plantarum KX838907 can be used in the commercial production of $\beta$-galactosidase as it is considered safe to use as a probiotic microorganism.

\section{ACKNOWLEDGEMENT}

The authors are thankful to the VIT, Tamil Nadu, and ICMR, New Delhi India for constant support to carry out the research project

\section{CONFLICT OF INTEREST}

On behalf of all authors, the corresponding author states that there is no conflict of interest.

\section{ABBREVIATIONS}

MRS: de Man, Rogosa and Sharpe; X-Gal: 5-bromo-4chloro-3-indolyl- $\beta$-D-galactopyranoside; ONPG: o-Nitrophenyl $\beta$-D-galactopyranoside; $\mathbf{N a}_{2} \mathbf{H P O}_{4}$ : Disodium phosphate; $\mathbf{N a H}_{2} \mathbf{P O}$ : Monosodium phosphate; KCl: Potassium chloride; $\mathbf{M g S O}_{4}$ : Magnesium sulfate; $\mathrm{Na}_{2} \mathrm{CO}_{3}$ : Sodium Carbonate; BLAST: Basic Local Alignment Search Tool; MEGA: Molecular Evolutionary Genetics Analysis; NCBI: National Center for Biotechnology Infomation; SEM: Scanning Electron Microscope; OFAT: One Factor at a Time; RSM: Response Surface Methodology; SDS-PAGE: Sodium dodecyl sulphate polyacrylamide gel electrophoresis; BSA: Bovine Serum Albumin; GOD-POD: Glucose Oxidase-Peroxidase; ANOVA: Analysis of Variance.

\section{REFERENCES}

1. De Vrese M, Stegelmann A, Richter B, Fenselau S, Laue C, Schrezenmeir J. Probiotics--compensation for lactase insufficiency. Am J Clin Nutr. 2001;73(2);Suppl:421S-9S. doi: 10.1093/ajcn/73.2.421s, PMID 11157352.

2. Karasova P, Spiwok V, Mala S, Kralova B, Russell N. Oligosaccharide synthesis using a-glucosides of different origins. Czech J Food Sci. 2002;20(2):43-7.

3. Pribila BA, Hertzler SR, Martin BR. Improved lactose digestion and Intolerance among african-American adolescent girls fed a dairy rich-diet. J Am Diet Asso. 2000;100(5):524-8.

4. Begley M, Hill C, Gahan CG. Bile salt hydrolase activity in probiotics. Appl Environ Microbiol. 2006;72(3):1729-38. doi: 10.1128/AEM.72.3.1729-1738.2006, PMID 16517616.

5. Richmond ML, Gray JI, Stine CM. Beta-Galactosidase: Review of Recent Research Related to Technological Application, Nutritional Concerns, and Immobilization. J Dairy Sci. 1981;64(9):1759-71. doi: 10.3168/jds.S00220302(81)82764-6.

6. Ladero M, Santos A, García-Ochoa F. Kinetic modeling of lactose hydrolysis with an immobilized beta-galactosidase from Kluyveromyces fragilis. Enzyme Microb Technol. 2000;27(8):583-92. doi: 10.1016/s0141-0229(00)00244-1, PMID 11024521.

7. Jurado E, Camacho F, Luzón G, Vicaria JM. A new kinetic model proposed for enzymatic hydrolysis of lactose by a $\beta$-galactosidase from Kluyveromyces fragilis. Enzy Microb Technol. 2002;31(3):300-9. doi: 10.1016/S01410229(02)00107-2.

8. Şener N, Kılıç Apar D, Özbek B. A modelling study on milk lactose hydrolysis and $\beta$-galactosidase stability under sonication. Process Biochem. 2006;41(7):1493-500. doi: 10.1016/j.procbio.2006.02.008.

9. Sumit $S$, Priyanka $S$. Isolation and characterization of $\beta$-galactosidase enzyme producing microbe and optimization of its enzyme activity under different culture conditions. Int J Curr Microbiol Appl Sci. 2014; 3(7);7706:2319.

10. Sen S, Ray L, Chattopadhyay P. Production, purification, immobilization, and characterization of a thermostable $\beta$-galactosidase from Aspergillus alliaceus. Appl Biochem Biotechnol. 2012;167(7):1938-53. doi: 10.1007/ s12010-012-9732-6, PMID 22639361.

11. Heilskov NS. Studies on animal lactase. II. Distribution in some of the glands of the digestive tract. Acta Physiol Scand. 1951;24(1):84-9. doi: 10.1111/ j.1748-1716.1951.tb00828.x, PMID 14877585. 
12. Santos A, Ladero M, García-Ochoa F. Kinetic Modeling of Lactose Hydrolysis by a $\beta$-Galactosidase from Kluyveromices Fragilis. Enzyme Microb Technol. 1998;22(7):558-67. doi: 10.1016/S0141-0229(97)00236-6.

13. Wallenfels K, Malhotra OP. Galactosidases. Advin carbo. Chem. 1972;16:239-98.

14. Adriano HDNR, Danielle CS, Stela AU, Jose GBGJ, Julio CDAN, Claudia DSM. Lactose intolerance and cow's milk protein allergy. Food Sci Technol. 2016; 36(2): 179-187.

15. Manuyakorn W, Tanpowpong P. Cow milk protein allergy and other common food allergies and intolerances. Paediatr Int Child Health. 2019;39(1):32-40. doi: 10.1080/20469047.2018.1490099, PMID 30014782.

16. Nivetha A, Srinivasan M. Screening and characterization of $\beta$-galactosidase producing Lactobacillus $\mathrm{sp}$. isolated from dairy samples. Res $\mathrm{J}$ Pharm Technol. 2018;11(5):1778-83. doi: 10.5958/0974-360X.2018.00330.X.

17. Miller $\mathrm{JH}$. Assay of beta-galactosidase. In: Miller $\mathrm{JH}$, editor experiments in molecular genetics. New York: cold spring harbor laboratory Press; 1998;3525.

18. Al-jazairi M, Abou-ghorrah S, Bakri Y. Isolation and identification of new yeast isolate with high beta-galactosidase activity from Syrian dairy products. Int Food Res J. 2014;21(2):541-6.

19. Altschul SF, Gish W, Miller W, Myers EW, Lipman DJ. Basic local alignment search tool. J Mol Biol. 1990;215(3):403-10. doi: 10.1016/S00222836(05)80360-2, PMID 2231712.

20. Saitou N, Nei M. The neighbor-joining method: a new method for reconstructing phylogenetic trees. Mol Biol Evol. 1987;4(4):406-25. doi: 10.1093/oxfordjournals.molbev.a040454, PMID 3447015.

21. McDougall LA, Holzapfel WH, Schillinger U, Feely DE, Rupnow JH. Scanning electron microscopy of target cells and molecular weight determination of a bacteriocin produced by Lactococcus lactis D53. Int J Food Microbiol. 1994;24(1-2):295-308. doi: 10.1016/0168-1605(94)90127-9, PMID 7703022.

22. Mozumder NHMR, Akhtaruzzaman M, Bakr MA, Zohra FT. Study on isolation and partial purification of lactase ( $\beta$-galactosidase) enzyme from Lactobacillus bacteria isolated from yogurt. J Sci Res. 2012;4(1):239-49. doi: 10.3329/jsr. v4i1.8478.
23. Selvarajan E, Mohanasrinivasan V. Kinetic studies on exploring lactose hydrolysis potential of $\beta$ galactosidase extracted from Lactobacillus plantarum HF571129. J Food Sci Technol. 2015;52(10):6206-17. doi: 10.1007/s13197015-1729-z, PMID 26396367.

24. Lowry $\mathrm{OH}$, Rosebrough NJ, Farr AL, Randall RJ. Protein measurement with the folin phenol reagent. J Biol Chem. 1951;193(1):265-75. doi: 10.1016/ S0021-9258(19)52451-6, PMID 14907713.

25. Murua A, Todorov SD, Vieira ADS, Martinez RCR, Cencič A, Franco BDGM. Isolation and identification of bacteriocinogenic strain of Lactobacillus plantarum with potential beneficial properties from donkey milk. J Appl Microbiol. 2013;114(6):1793-809. doi: 10.1111/jam.12190, PMID 23489977.

26. Siham AAI, Yasser EM, Wafaa AH, Rasha AR, Amal MH. Cultural condition affecting the growth and production of beta-galactosidase by Lactobacillus acidophilus NRRL 4495. Aust J Basic Appl Sci. 2010;8(4):5051-8.

27. Yapi DY, Gnakri D, Niamke SL, Kouame LP. Purification and biochemical characterization of a specific $\beta$-glucosidase from the digestive fluid of larvae of the palm weevil, Rhynchophorus palmarum. J Insect Sci. 2009;9(4):1-13. doi: 10.1673/031.009.0401.

28. Sunitha K, Lee J, Oh T. Optimization of medium components for phytase production by $E$. coli using response surface methodology. Bioprocess Eng. 1999;21(6):477-81. doi: 10.1007/PL00009086.

29. Osorio NM. Response Surface modelling of the production of V3 polyunsaturated fatty acids-enriched fats by a Commercial Immobilized Lipase. J Mol Catal B Enzym. 2001;11(4):677-86.

30. Heba. Ezz EDY, Beltagey AE. Extraction purification and characterization of apricot seed $\beta$-galactosidase for producing free lactose cheese. Nutr Food Sci. 2014;4(2):270.

31. Elmira G, Fariba H, Bahareh KS, Jamileh N, Farahnaz M. Study on $\beta$-galactosidase enzyme produced by isolated Lactobacilli from milk and cheese. A J Micro Res. 2010;4(6):454-8.

32. Selvarajan E, Mohanasrinivasan V, Devi CS, Doss CG. Immobilization of $\beta$-galactosidase from Lactobacillus plantarum HF571129 on ZnO nanoparticles: Characterization and lactose hydrolysis. Bioprocess Biosyst Eng. 2015;38(9):1655-69. doi: 10.1007/s00449-015-1407-6, PMID 25924968.

\section{SUMMARY}

The main aim of the research is to solve the most appropriate problem in abdominal clinical practice LACTOSE INTOLERANCE which causes a major issue in the digestive system when there is a lack of a $\beta$-galactosidase enzyme. The present study mainly focuses on the production, optimization, and purification of the $\beta$-galactosidase enzyme from Lactobacillus plantarum VITDM15. Lactic Acid Bacteria (LAB) isolated from donkey milk, curd, and yogurt in MRS media. Further, the isolates screened for $\beta$-galactosidase using an $\mathrm{X}$-gal assay.

The one potent isolate VITDM15 isolated from donkey milk revealed maximum $\beta$-galactosidase production in the hydrolysis of o-Nitrophenyl $\beta$-D-galactopyranoside (ONPG) as the substrate. The partial sequence obtained from $16 \mathrm{~S}$ rRNA was constructed for the phylogenetic tree using MEGA software by the neighbor join method. VITDM15 exhibited 99\% similarity with L. plantarum and gene sequence submitted in the NCBI to obtain accession number. Optimized media enhanced the maximum $\beta$-galactosidase activity in lactose as a carbon source followed by beef extract as a nitrogen source. The enzyme was more active in temperatures ranging from $30^{\circ} \mathrm{C}$ to $40^{\circ} \mathrm{C}$. The Stability of the $\mathrm{pH}$ for enzyme production was 7 . The effect of their interactions on $\beta$-galactosidase production was further confirmed using RSM the statistical tool with a D-optimal experimental design in $3 \mathrm{D}$ interaction. The $\beta$-galactosidase enzyme was precipitated using $70 \%$ ammonium sulfate precipitation followed by ultracentrifugation and eluted in gel permeation chromatography. The molecular weight of the protein was $112 \mathrm{Kda}$ in SDS-PAGE. Purified $\beta$-galactosidase from L. plantarum KX838907 was yielded $31.75 \%$ with 67.73 fold and specific activity of $1705 \mathrm{IU} / \mathrm{mg}$. Further, the enzyme was immobilized by $2 \%$ sodium alginate to make lactose-free milk. In the milk treated with purified $\beta$-galactosidase, the glucose dosage increased up to a maximum level of $4.891 \mathrm{mg} / 1$ in the $4^{\text {th }}$ cycle in GOD-POD assay. From the results obtained in the study, it was summarized that the novel strain L. plantarum VITDM15 can efficiently produce the $\beta$-galactosidase enzyme. Thus L. plantarum can be used in the commercial production of $\beta$-galactosidase as it is considered safe to use as a probiotic microorganism and it also gives high enzyme yield. 


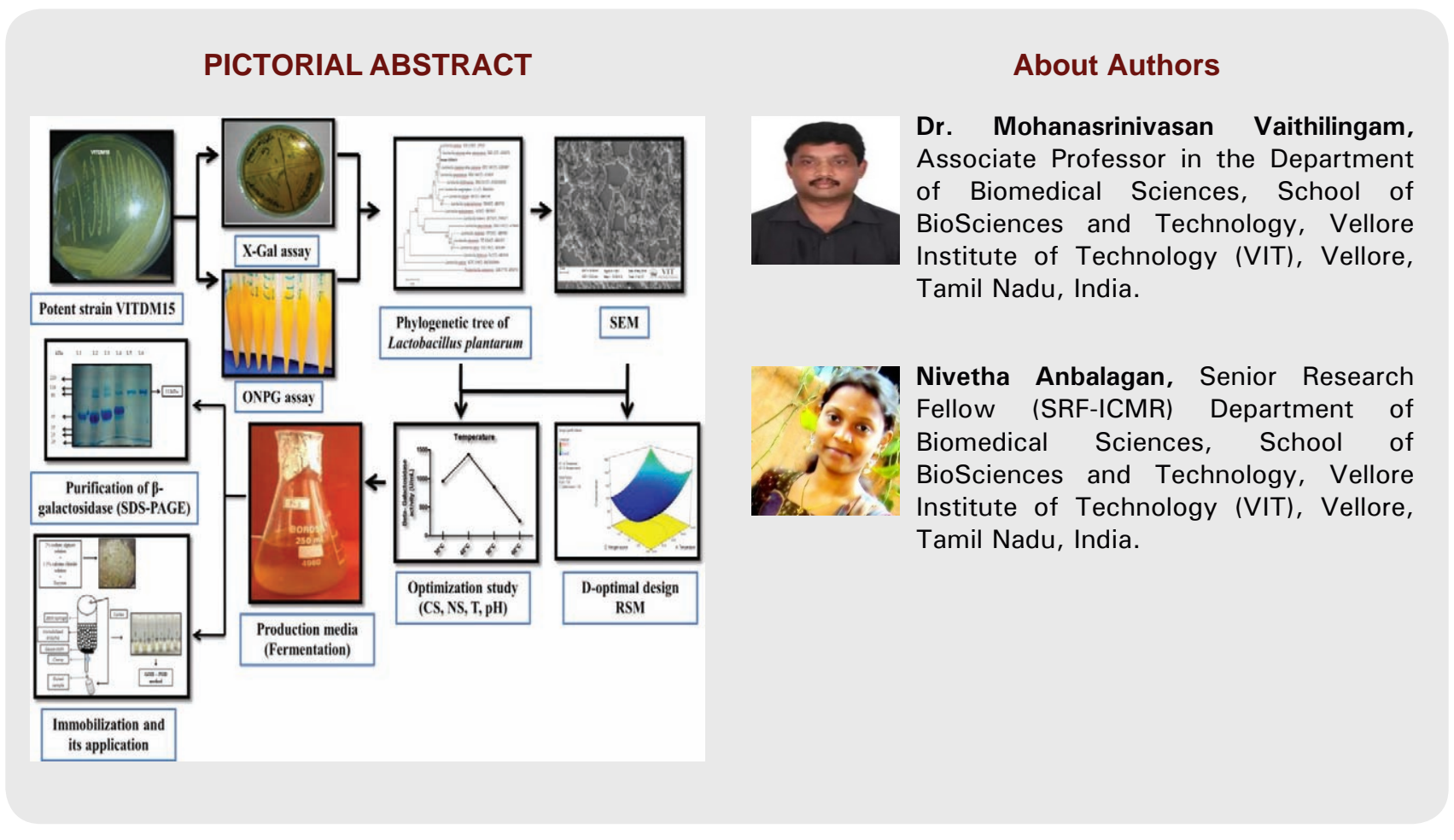

Cite this article: Anbalagan N, Vaithiyalingam M. An Experimental Study using the Statistical Tool D-optimal Design for the Process Optimization to Enhance the Yield of $\beta$-galactosidase from Lactobacillus plantarum. Indian $\mathrm{J}$ of Pharmaceutical Education and Research. 2021;55(4):1096-106. 